\title{
Guabijú (Myrcianthes pungens): Characterization of in natura and lyophilized
}

\section{Brazilian berry}

\author{
Guabijú (Myrcianthes pungens): Caracterização de uma baga brasileira in natura e liofilizada \\ Guabijú (Myrcianthes pungens): Caracterización de baya brasileña in natura y liofilizada
}

Received: 02/26/2021 | Reviewed: 03/07/2021 | Accept: 03/12/2021 | Published: 03/19/2021

Elisandra Detoni

ORCID: https://orcid.org/0000-0002-2293-3042

Universidade Tecnológica Federal do Paraná, Brazil

E-mail: elisandradetoni@ hotmail.com

Daneysa Lahis Kalschne

ORCID: https://orcid.org/0000-0002-8618-9363

Universidade Tecnológica Federal do Paraná, Brazil

E-mail: daneysa@hotmail.com

Anandra Bendendo

ORCID: https://orcid.org/0000-0002-7910-5942

Universidade Tecnológica Federal do Paraná, Brazil E-mail: anandrabedendo@gmail.com

Nathalia Karen Silva

ORCID: https://orcid.org/0000-0002-2082-0511

Universidade Tecnológica Federal do Paraná, Brazil E-mail: nathaliakaren96@gmail.com

Oldair Donizeti Leite

ORCID: https://orcid.org/0000-0003-2554-3696

Universidade Tecnológica Federal do Paraná, Brazil

E-mail: oldair.leite@gmail.com

Angela Claudia Rodrigues

ORCID: https://orcid.org/0000-0002-1474-1526

Universidade Tecnológica Federal do Paraná, Brazil

E-mail: angelac.utfpr@gmail.com

\begin{abstract}
The guabiju (Myrcianthes pungens) is a fruit native from Brazil, characterized by its pleasant sweet flavor, yellow pulp and purple skin in the ripe stage. Its maturation period occurs between december and april in the southern regions of Brazil. The aim of this study was to evaluate the physico-chemical characteristics of guabiju in natura and lyophilized from two different harvest times (December and January). The proximal composition, bioactive profile (anthocyanins, phenolic compounds, and antioxidant activity), mineral profile $(\mathrm{Ca}, \mathrm{Cu}, \mathrm{Fe}, \mathrm{Mg}, \mathrm{Mn}, \mathrm{K}$, and $\mathrm{Zn}$ ), and color parameters $\left(\mathrm{L}^{*}, \mathrm{a}^{*}\right.$, and $\left.\mathrm{b}^{*}\right)$ were evaluated. The fruits from January presented a higher content of carbohydrates, reducing sugars, antioxidant potential, and more intense characteristic color, while the fruits from December showed a higher total anthocyanin and mineral content. Moreover, the samples submitted to lyophilization showed good retention of bioactives, highlighting as a suitable method of processing to increase the stability without profound physico-chemical changes. In the colorimetric analysis, the lyophilized samples have a higher intensity of red color, especially in guabijú from January. Both guabijú forms (in natura and lyophilized) from two harvesting times were considered a source of bioactives, with great potential for application in foods.
\end{abstract}

Keywords: Anthocyanins; Freeze drying; Mineral; Polyphenol; Principal component analysis; Proximal composition.

\section{Resumo}

O guabijú (Myrcianthes pungens) é um fruto nativo do Brasil, caracterizado por seu agradável sabor adocicado, polpa amarela e casca roxa na fase madura. Seu período de maturação ocorre entre dezembro e abril na região sul do Brasil. O objetivo deste estudo foi avaliar as características físico-químicas do guabijú in natura e liofilizado em duas épocas de colheita (dezembro e janeiro). A composição proximal, perfil bioativo (antocianinas, compostos fenólicos e atividade antioxidante), perfil mineral ( $\mathrm{Ca}, \mathrm{Cu}, \mathrm{Fe}, \mathrm{Mg}, \mathrm{Mn}, \mathrm{K}$ e $\mathrm{Zn})$ e parâmetros de cor ( $\mathrm{L}^{*}, \mathrm{a}^{*}$ e $\left.\mathrm{b}^{*}\right)$ foram avaliados. As frutas de janeiro apresentaram maior teor de carboidratos, açúcares redutores, potencial antioxidante e cor característica mais intensa, enquanto as frutas de dezembro apresentam maior teor de antocianinas totais e minerais. Além disso, as amostras submetidas à liofilização apresentaram boa retenção de bioativos, destacando-se como um método de processamento adequado para aumentar a estabilidade sem alterações físico-químicas profundas. $\mathrm{Na}$ análise colorimétrica, as amostras liofilizadas apresentam maior intensidade de coloração vermelha, 
principalmente no guabijú colhido em janeiro. Ambas as formas de guabijú (in natura e liofilizado) de duas épocas de colheita foram consideradas fonte de bioativos, com grande potencial para aplicação em alimentos.

Palavras-chave: Antocianinas; Liofilização; Mineral; Polifenol; Análise de componentes principais; Composição proximal.

\begin{abstract}
Resumen
El guabijú (Myrcianthes pungens) es una fruta originaria de Brasil, caracterizada por su agradable sabor dulce, pulpa amarilla y piel morada en la etapa madura. Su período de maduración ocurre entre diciembre y abril en las regiones del sur de Brasil. El objetivo de este estudio fue evaluar las características físico-químicas del guabijú in natura y liofilizado en dos épocas de cosecha diferentes (diciembre y enero). Composición proximal, perfil bioactivo (antocianinas, compuestos fenólicos y actividad antioxidante), perfil mineral ( $\mathrm{Ca}, \mathrm{Cu}, \mathrm{Fe}, \mathrm{Mg}, \mathrm{Mn}, \mathrm{K}$ y $\mathrm{Zn}$ ) y parámetros de color ( $\mathrm{L}^{*}, \mathrm{a}^{*} \mathrm{y} \mathrm{b}^{*}$ ) fueron evaluados. Los frutos de enero tienen mayor contenido de carbohidratos, azúcares reductores, potencial antioxidante y color característico más intenso, mientras que los frutos de diciembre presentan mayor contenido de antocianinas totales y minerales. Además, las muestras sometidas a liofilización mostraron buena retención de bioactivos, destacándose como un método de procesamiento adecuado para aumentar la estabilidad sin cambios físico-químicos profundos. En el análisis colorimétrico, las muestras liofilizadas presentan mayor intensidad de color rojo, especialmente en guabijú a partir de enero. Ambas formas de guabijú (in natura y liofilizado) de dos tiempos de cosecha fueron consideradas fuente de bioactivos, con gran potencial de aplicación en alimentos.
\end{abstract}

Palabras clave: Antocianinas; Secar en frío; Mineral; Polifenol; Análisis de componentes principales; Composición proximal.

\title{
1. Introduction
}

Wild fruits present great genetic diversity, and fruit consumption is associated with health benefits due to the presence of antioxidants, phytochemicals, minerals, vitamins, and fibers (Betta et al., 2018; Seraglio et al., 2018). Guabijú (Myrcianthes pungens) is a fruit native from Brazil, belonging to the Myrtaceae family, disposed of in tropical and subtropical regions of the world and abundant throughout the Brazilian territory (Seraglio et al., 2018).

The fruit has the indigenous name wa'bi (edible) yu (yellow), is consumed in regions where the species is popularly known and does not have large-scale trade (Andrade et al., 2011; Sarmento et al., 2012). Its occurrence is more common in the South country; however, it may be found between the States of São Paulo and Rio Grande do Sul and in countries such Argentina, Uruguay, Paraguay, and Bolivia (Burckhardt et al., 2012; Fior et al., 2010). The fruit is a rounded berry with purple shell and yellowish pulp with one to two seeds, and its juicy pulp has a pleasant sweet taste (Dalla Nora, Jablonski, et al., 2014; Kalschne et al., 2019). The Guabijú is largely consumed in natura form; however, it may be used in the preparation of sweets, jellies, juices, and liqueurs (Sarmento et al., 2012; Souza, 2010).

Guabijúzeiro fruits are reported in the literature as a source of bioactive compounds, including anthocyanins and phenolic compounds (Andrade et al., 2011; Dalla Nora, Jablonski, et al., 2014; Kalschne et al., 2019; Seraglio et al., 2018). These compounds have antioxidant activity, preventing the deterioration of oxidizable products in food and cosmetics. Antioxidants are also beneficial for human health, acting in the fight against free radicals that cause imbalance in the body and are associated with degenerative diseases such as Alzheimer's (Chen et al., 2015).

Guabijú is a seasonal fruit, and the ripeness period occurs between the months of December and April and may vary according to the region and planting conditions of the species. The harvest time of the fruits may also interfere with the nutritional composition, with changes in the mineral content and bioactive profile. To improve the supply of fruit and its compounds for longer periods, reducing losses and waste, it is necessary to apply processing technologies for conservation. Fruit dehydration is an important technique that adds value to the final product and increases its application and subsequent shelf life, facilitating its commercialization. This processing technique promotes the reduction of water activity, preventing microbiological degradation and reducing undesirable biochemical reactions in food. Lyophilization is a drying method that uses vacuum and low temperatures to remove water from food. The process occurs by sublimating the frozen product. The 
conditions of low pressure and temperature involved are fundamental in preserving the nutritional quality of the food. In comparison to other drying methods, lyophilization is considered one of the best techniques to be used in fruit dehydration, since it maintains characteristic aspects such as color and nutrient retention, in addition to preventing microbiological deterioration and biochemical reactions (Schwartz et al., 2017; Vieira et al., 2012).

In addition, studies describing the use of fruits, their processing, and the physico-chemical profile of a Brazilian native berry such as guabijú are scarce. To our knowledge, only a few studies have evaluated the guabijú bioactive profile (Andrade et al., 2011; Betta et al., 2018; Dalla Nora, Jablonski, et al., 2014; Dalla Nora, Müller, et al., 2014; Seraglio et al., 2018). In this context, the aim of this study was to evaluate the physico-chemical characteristics of guabijú in natura and lyophilized from two different harvest times. The proximal composition, bioactive and mineral profile, and color parameters were evaluated.

\section{Methodology}

\section{Preparation of the fruits}

Guabijú fruits were collected in the city of Francisco Beltrão (latitude: $26^{\circ} 04$ '52 "S; longitude: 53 03' 18"; altitude: $570 \mathrm{~m}$ ), Paraná (Brazil) of different plants, in the period December 2018 and January 2019. Ripe fruits with no skin defects were selected, packaged, and frozen at $-18{ }^{\circ} \mathrm{C}$ until use. The fruit seeds were removed, and the pulp with shells was disposed of in an aluminum tray before lyophilization. The drying process was performed in a Labconco lyophilizer (FreeZone 6L, Kansas, EUA) at $60{ }^{\circ} \mathrm{C}$ for $\approx 48 \mathrm{~h}$ to ensure water removal. The dried fruits were milled (IKA A11 basic, Staufen, Germany) until a fine powder was obtained (32\% retrieved in 20 mesh, $18 \%$ retrieved 30 mesh, $38 \%$ retrieved 50 mesh and the rest was $<60$ mesh), stored in a plastic bag and frozen at $-22^{\circ} \mathrm{C}$. In this way, four samples were obtained: (1) GIND - guabiju in natura from December; (2) GINJ - guabijú in natura from January; (3) GLPD - guabijú lyophilized in powder from December; and (4) GLPJ - guabijú lyophilized in powder from January; all samples were analyzed in triplicate.

\section{Chemical physical parameters}

The parameters of titratable acidity, ash, carbohydrates, lipids, $\mathrm{pH}$, proteins, and moisture were determined according to the methodology of Instituto Adolfo Lutz (IAL, 2008). The total soluble solids ( ${ }^{\circ}$ Brix) was determined only in guabijú in natura using the Abbé refractometer (IAL, 2008). The ratio value (soluble solids/acidity) was also determined for these samples.

The total sugars were determined by dinitrosalicylic acid (DNS) according to Maldonade et al. (2013). An aqueous extract was prepared by dispersion of guabijú in natura $(10 \mathrm{~g})$ or lyophilized $(10 \mathrm{~g})$ in $100 \mathrm{~mL}$ of water, diluted, subjected to the DNS test, and measured at $540 \mathrm{~nm}$ in a UV-Vis spectrophotometer (Perkin Elmer, Beaconsfield, UK). A calibration curve of glucose in distilled water was prepared in the range of 0.10 to $1.0 \mathrm{~g} \times \mathrm{L}^{-1}$. The final result was expressed in $\mathrm{g}$ of reducing sugar $\times 100 \mathrm{~g}^{-1}$ of fruit $\left(\mathrm{g}\right.$ RS $\times 100 \mathrm{~g}^{-1}$ sample) .

\section{Antioxidant activity}

The antioxidant activity was determined using the 2,2-diphenyl-1-picryl-hydrazil free radical capture method (DPPH; Sigma Aldrich, Saint Louise, USA) according to the methodology described by Brand-Williams et al. (1995) with modifications made by Rufino et al. (2007). An aqueous extract was produced using guabijú in natura $(10 \mathrm{~g})$ and lyophilized $(10 \mathrm{~g})$ with $50 \%$ methyl alcohol $(40 \mathrm{~mL})$ and $70 \%$ acetone $(40 \mathrm{~mL})$. The final $100 \mathrm{~mL}$ volume was made up of distilled water. The extract was adequately diluted and transferred to tubes with DPPH reagent, protected from light. After the reaction period (30 - $60 \mathrm{~min}$ ), the absorbance was measured in a UV-Vis spectrophotometer (Perkin Elmer) at $515 \mathrm{~nm}$ using a P.A. methyl 
alcohol for calibration. A calibration curve was constructed with DPPH solution from 0.01 to $0.06 \mathrm{~mol} \times \mathrm{L}^{-1}$. The result was expressed as $\mathrm{EC}_{50}$.

\section{Phenolic compounds}

The total phenolic compounds were determined by the Folin-Ciocalteu method (Sigma Aldrich) according to Singleton et al. (1999) with some modifications. The aqueous extract $(100 \mathrm{~mL})$ of in natura and lyophilized guabijú, previously used in the analysis of antioxidant, was diluted properly and placed in tubes with reagent Folin-Ciocalteu. In the

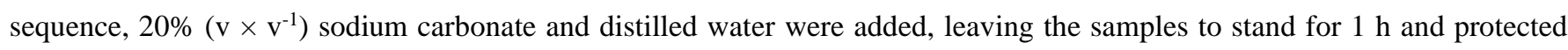
from light. The absorbance was read on a UV-Vis spectrophotometer at $765 \mathrm{~nm}$. A calibration curve for gallic acid in the range of 0.2 to $2.5 \mathrm{~g} \times \mathrm{L}^{-1}$ was constructed using the same conditions described for the samples. The result was expressed in $\mathrm{mg}$ of gallic acid $\times 100 \mathrm{~g}^{-1}$ of fruit.

\section{Total anthocyanin}

The total anthocyanin content was determined as described by Francis, (1982) with some modifications. An extract was prepared with guabijú in natura $(5.0 \mathrm{~g})$ and freeze-dried guabijú $(5.0 \mathrm{~g})$ diluted in $30 \mathrm{~mL}$ of extracting solution prepared

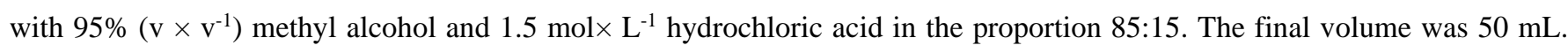
The samples were protected from light and allowed to steep at $5{ }^{\circ} \mathrm{C}$ for $12 \mathrm{~h}$. A dilution of the aqueous extract was carried out, and the absorbance was measured in a UV-Vis spectrophotometer at $535 \mathrm{~nm}$. The result was expressed in $\mathrm{mg}$ of total anthocyanin $\times 100 \mathrm{~g}^{-1}$ of fruit.

\section{Mineral profile}

The determination of minerals was performed only in lyophilized samples. The minerals $\mathrm{Ca}, \mathrm{Cu}, \mathrm{Fe}, \mathrm{Mg}, \mathrm{Mn}, \mathrm{K}$, and $\mathrm{Zn}$ were determined according to Kalschne et al. (2020) in triplicate. Each sample was weighed $(0.400 \mathrm{~g})$ in $50 \mathrm{~mL}$ PTFE-TFM closed vessels (supporting $310{ }^{\circ} \mathrm{C}$ and 40 bar), added to $3 \mathrm{~mL}$ of $\mathrm{HNO}_{3}\left(65 \% \mathrm{~m} \times \mathrm{v}^{-1}\right)$ and $2 \mathrm{~mL}$ of $\mathrm{H}_{2} \mathrm{O}_{2}\left(30 \% \mathrm{v} \times \mathrm{v}^{-1}\right)$ and left at room temperature without closing for $20 \mathrm{~min}$. The samples were submitted to wet digestion performed using a microwave furnace (Multiwave $\mathrm{GO}^{\circledR}$, Anton Paar, Graz, Austria) using the digestion method USEPA 3052- in the first step, the temperature was linearity increased up to $180^{\circ} \mathrm{C}$ in $4.5 \mathrm{~min}$ and kept for $9.5 \mathrm{~min}$ followed by cooling.

\section{Colorimetric analysis}

Color analysis was performed using a colorimeter (CR 400, Konica Minolta, Tokyo, Japan) with an integrating sphere and $45^{\circ}$ viewing angle (lighting $\mathrm{d} / 45$ and illuminating $\mathrm{D}$ ). The parameters $\mathrm{L}^{*}$ (luminosity), $\mathrm{a}^{*}$ (coordinate green-red), and $\mathrm{b}^{*}$ (coordinate blue-yellow) were determined.

\section{Statistical analysis}

The data obtained are expressed as the mean \pm standard deviation $(n=3)$. The data were submitted to $t$-test, analysis of variance (ANOVA), Tukey's test $(\mathrm{p}<0.05)$, and principal component analysis (PCA) using the software Statistica version 8.0. 


\section{Results and Discussion}

The guabijú fruits collected in both December and January had a surface purple color, which was kept in the lyophilized fruits and in the powder obtained after milling. However, the fruits from January had a purple color that was more intense. Figure 1 details the visual characteristics of the samples.

Figure 1: Guabijú in natura, lyophilized, and lyophilized powdered.

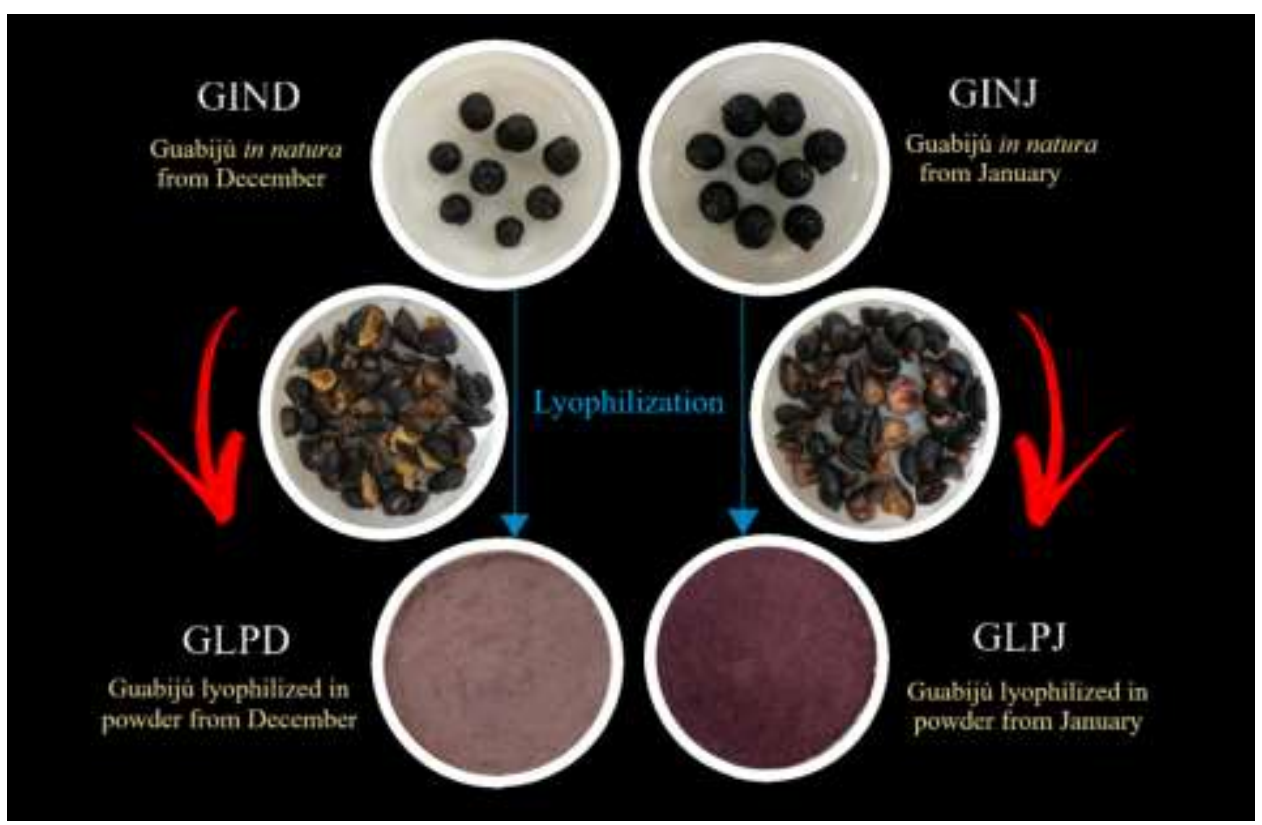

Source: Authors.

The results obtained in the physico-chemical characterization of the guabijú in natura and lyophilized from December and January are detailed in Table 1.

Table 1: Physico-chemical characterization of guabijú in natura from December (GIND) and January (GIND) and lyophilized from December (GLPD) and January (GLPJ).

\begin{tabular}{|c|c|c|c|c|}
\hline Parameters & GIND & GINJ & GLPD & GLPJ \\
\hline Moisture ( $\mathrm{g} \times 100 \mathrm{~g}^{-1}$ w.b. $)$ & $77.11 \pm 0.32^{\mathrm{a}}$ & $77.49 \pm 0.37^{\mathrm{a}}$ & $9.02 \pm 0.29^{\mathrm{B}}$ & $11.96 \pm 0.47^{\mathrm{A}}$ \\
\hline Lipid $\left(g \times 100 g^{-1}\right.$ d.b. $)$ & $0.82 \pm 0.00^{\mathrm{a}}$ & $0.84 \pm 0.02^{\mathrm{a}}$ & $1.62 \pm 0.05^{\mathrm{A}}$ & $1.21 \pm 0.06^{\mathrm{B}}$ \\
\hline Protein $\left(\mathrm{g} \times 100 \mathrm{~g}^{-1} \mathrm{~d} . \mathrm{b}.\right)$ & $3.23 \pm 0.29^{\mathrm{a}}$ & $2.47 \pm 0.21^{\mathrm{b}}$ & $3.35 \pm 0.03^{\mathrm{A}}$ & $3.73 \pm 0.06^{\mathrm{A}}$ \\
\hline Ash $\left(g \times 100 g^{-1}\right.$ d.b. $)$ & $2.32 \pm 0.04^{\mathrm{a}}$ & $2.25 \pm 0.04^{\mathrm{a}}$ & $3.04 \pm 0.04^{\mathrm{A}}$ & $2.98 \pm 0.09^{\mathrm{A}}$ \\
\hline Carbohydrate $\left(\mathrm{g} \times 100 \mathrm{~g}^{-1}\right.$ d.b. $)$ & $93.63 \pm 0.29^{b}$ & $94.44 \pm 0.21^{\mathrm{a}}$ & $91.99 \pm 0.07^{\mathrm{B}}$ & $92.08 \pm 0.12^{\mathrm{A}}$ \\
\hline $\mathrm{pH}$ & $4.69 \pm 0.03^{\mathrm{a}}$ & $4.63 \pm 0.03^{\mathrm{a}}$ & $4.57 \pm 0.01^{\mathrm{A}}$ & $4.52 \pm 0.03^{\mathrm{A}}$ \\
\hline TTA (g citric acid $\left.\times 100 \mathrm{~g}^{-1}\right)$ & $0.16 \pm 0.00^{\mathrm{b}}$ & $0.22 \pm 0.10^{\mathrm{a}}$ & $1.22 \pm 0.01^{\mathrm{B}}$ & $1.49 \pm 0.02^{\mathrm{A}}$ \\
\hline TSS ( ${ }^{\circ}$ Brix $)$ & $13.57 \pm 0.14^{b}$ & $17.03 \pm 0.07^{\mathrm{a}}$ & - & - \\
\hline Ratio (TSS/TTA) & $83.99 \pm 1.46^{\mathrm{a}}$ & $77.74 \pm 3.13^{\mathrm{b}}$ & - & - \\
\hline $\mathrm{RS}\left(\mathrm{g} R \mathrm{RS} \times 100 \mathrm{~g}^{-1}\right)$ & $5.47 \pm 0.01^{\mathrm{b}}$ & $6.53 \pm 0.03^{\mathrm{a}}$ & $16.02 \pm 0.03^{\mathrm{B}}$ & $19.50 \pm 0.03^{\mathrm{A}}$ \\
\hline
\end{tabular}

TTA: titratable total acidity; TSS: total soluble solids; RS: reducing sugar; w.t.: wet base; d.b.: dry base; Means \pm standard deviation (n = 3); different superscript letters (lowercase for guabijú in natura; uppercase for guabijú lyophilized) in the lines indicate a significant difference by the t-test $(\mathrm{p}<0.05)$. Source: Authors. 
The moisture, lipid, ash, and $\mathrm{pH}$ contents did not differ between guabijú in natura from the two harvests (p >0.05); however, they moisture of guabijú in natura was 7 times an average higher than guabijú lyophilized. Regarding lyophilized fruits, no difference was observed between the content of ash, protein, and pH. The moisture content of GIND (77.11 $\mathrm{g} \times 100$ $\left.\mathrm{g}^{-1}\right)$ and GINJ $\left(77.49 \mathrm{~g} \times 100 \mathrm{~g}^{-1}\right)$ represented a high-water content in their composition. The obtained values were lower than the values reported for the same species in the literature, from 80.79 to $83.19 \mathrm{~g} \times 100 \mathrm{~g}^{-1}$ (Dalla Nora, Jablonski, et al., 2014; Seraglio et al., 2018), and lower compared with fruits from the same botanical family, such as red $\operatorname{araçá~}\left(81.56 \mathrm{~g} \times 100 \mathrm{~g}^{-1}\right)$ (Dalla Nora, Jablonski, et al., 2014) and jabuticaba (84.56 $\left.\mathrm{g} \times 100 \mathrm{~g}^{-1}\right)$ (Seraglio et al., 2018). The high humidity favors the low stability of the fruits in the fresh form, which justifies its drying to obtain a longer shelf life.

The lipid contents of GIND and GINJ ( 0.82 and $0.84 \mathrm{~g} \times 100 \mathrm{~g}^{-1}$, respectively) were higher than the $0.28 \mathrm{~g}^{\circ} 100 \mathrm{~g}^{-1}$ value reported by Dalla Nora, Jablonski, et al. (2014) for guabijú fruit. Moreover, guabijú also presents a higher lipid content than fruits of the same botanical family, such as purple, red, and orange pitanga analyzed by Bagetti et al. (2011) with lipid values between 0.4 and $0.5 \mathrm{~g} \times 100 \mathrm{~g}^{-1}$. This result may be associated with the lower moisture of guabijú in natura evaluated (77.11 and $77.49 \mathrm{~g} \times 100 \mathrm{~g}^{-1}$ ) compared with a moisture of 80.79 and $84.7 \mathrm{~g} \times 100 \mathrm{~g}^{-1}$ ).

The protein and ash slightly increased with lyophilization; in contrast, the carbohydrate slightly decreased. For

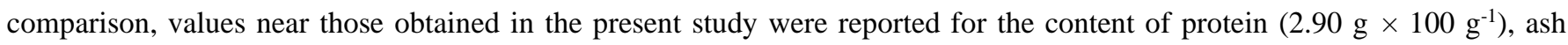
$\left(3.07 \mathrm{~g} \times 100 \mathrm{~g}^{-1}\right)$, and total carbohydrate (fiber + carbohydrate $\left.=96.05 \mathrm{~g} \times 100 \mathrm{~g}^{-1}\right)$ for guabijú fruit Dalla Nora, Jablonski, et al. (2014).

The $\mathrm{pH}$ values obtained for guabijú in natura and lyophilized were in the range reported for guabijú fruit, from 4.60 to 5.52 (Dalla Nora, Jablonski, et al., 2014; Seraglio et al., 2018). The titratable total acidity (TTA), total soluble solids (TSS), sugars, and ratio (TSS/TTA) values were significantly different between guabijú in natura (Table 1). GINJ presented a higher content of TTA, sugars, and TSS ( $<<0.05)$. The TSS are used as the ripeness index for some fruits and may vary with the cultivar, soil, precipitation, processing, and climatic conditions (Castro et al., 2015). These factors may explain the lower TSS content for the GIND sample.

The TTA values determined in the present study for guabijú in natura were higher than those reported for fresh guabijú by Dalla Nora, Jablonski, et al. (2014) of $0.12 \mathrm{~g}$ of citric acid $\times 100 \mathrm{~g}^{-1}$. The TSS observed for GIND and GINJ are near the range described for the same fruit (11.00 to $15.00^{\circ}$ Brix) by other authors (Dalla Nora, Jablonski, et al., 2014; Seraglio et al., 2018). The acidity, in general, tends to decrease with the fruit ripening process, and both TTA and SST promote the flavor characteristics of the fruits (Castro et al., 2015). The sugar content for guabijú in natura was significantly different between harvests, with the highest content found for GINJ (GIND: $5.47 \mathrm{~g}$ RS $\times 100 \mathrm{~g}^{-1}$; GINJ: $6.53 \mathrm{~g}$ RS $\times 100 \mathrm{~g}^{-1}$ ). Based on the values obtained for TTA, TSS, and sugars, guabijú can be considered a sweet fruit (Seraglio et al., 2018).

The value of the ratio obtained for GINJ was lower than that obtained for GIND ( $p<0.05$ ), which can be associated with the greater acidity of GINJ fruit $\left(0.22 \mathrm{~g}\right.$ of citric acid $\left.\times 100 \mathrm{~g}^{-1}\right)$. This ratio represents a balance of organic acids and sugars, since the sweetness perceived in high-acidity fruits is a result of this balance (Castro et al., 2015). Both guabijú in natura analyzed present lower ratios compared to the value of 125.00 reported by Dalla Nora, Jablonski, et al. (2014). A higher value for the ratio indicates a suitable degree of ripeness for fruits, since it increases when there is a decrease in TTA and a high content of TSS. The differences observed between the parameters of moisture, lipids, protein, ash, TTA, and reducing sugars between guabijú in natura and lyophilized are related to fruit processing. Lyophilization removes water from the food and concentrates solids, including sugars, acids, salts, and other components of the food.

For guabijú lyophilized (GLPD and GLPJ), the content of ash, proteins, and pH did not differ between December and January harvest. In contrast, the moisture, carbohydrates, lipids, TTA, and reducing sugars were significantly different ( $\mathrm{p}<$ 0.05). It is important to emphasize that although some parameters did not differ in guabijú in natura, when moisture is 
eliminated by the drying process, some variations in composition become more expressive and associated with the conditions of cultivation and management, differing according to the period of harvest and maturation.

The results obtained for $\mathrm{pH}$ and TTA of guabijú lyophilized from both harvests (Table 1) characterize it with a low acid product. Lamounier et al. (2015) produced a flour from jabuticaba peel and obtained a pH of 3.27 and TTA of $9.4 \mathrm{~g}$ citric acid $\times 100 \mathrm{~g}^{-1}$, which presented a greater acidity compared to GLPD and GLPJ. The authors also obtained higher ash (4.23 $\mathrm{g} \times$ $\left.100 \mathrm{~g}^{-1}\right)$ and moisture $\left(16.13 \mathrm{~g} \times 100 \mathrm{~g}^{-1}\right)$ contents compared to guabijú lyophilized. In addition to the comparison of different species, guabijú is not pulped for manufacturing and lyophilization, contributing to its low acidity and proximal composition.

The total anthocyanin compounds, total phenolic compounds, antioxidant activity, and mineral compounds are detailed in Table 2. All samples analyzed for total anthocyanin compounds, total phenolic compounds, and antioxidant activity had significant differences $(p>0.05)$.

Table 2: Characterization of bioactives and minerals of guabijú in natura from December (GIND) and January (GIND) and lyophilized from December (GLPD) and January (GLPJ).

\begin{tabular}{ccccc}
\hline Parameters & GIND & GINJ & GLPD & GLPJ \\
\hline TAC $\left(\mathrm{mg} \times 100 \mathrm{~g}^{-1}\right)$ & $19.22 \pm 0.00^{\mathrm{b}}$ & $68.75 \pm 0.30^{\mathrm{a}}$ & $220.12 \pm 0.60^{\mathrm{A}}$ & $201.07 \pm 1.37^{\mathrm{B}}$ \\
$\mathrm{TPC}\left(\mathrm{mg} \mathrm{GAE} \times 100 \mathrm{~g}^{-1}\right)$ & $609.50 \pm 3.79^{\mathrm{b}}$ & $698.04 \pm 3.77^{\mathrm{a}}$ & $1822.68 \pm 7.60^{\mathrm{B}}$ & $1919.23 \pm 7.60^{\mathrm{A}}$ \\
$\mathrm{EC}_{50}\left(\mathrm{~g} \times \mathrm{g}^{-1} \mathrm{DPPH}\right)$ & $320.36 \pm 10.47^{\mathrm{a}}$ & $131.34 \pm 1.49^{\mathrm{b}}$ & $60.29 \pm 3.57^{\mathrm{A}}$ & $38.87 \pm 0.70^{\mathrm{B}}$ \\
$\mathrm{Ca}\left(\mu \mathrm{g} \times \mathrm{g}^{-1}\right)$ & - & - & $3925.21 \pm 10.94^{\mathrm{A}}$ & $3571.72 \pm 81.52^{\mathrm{B}}$ \\
$\mathrm{Cu}\left(\mu \mathrm{g} \times \mathrm{g}^{-1}\right)$ & - & - & $2.44 \pm 0.04^{\mathrm{A}}$ & $2.47 \pm 0.06^{\mathrm{A}}$ \\
$\mathrm{Fe}\left(\mu \mathrm{g} \times \mathrm{g}^{-1}\right)$ & - & - & $16.92 \pm 1.05^{\mathrm{A}}$ & $9.23 \pm 0.58^{\mathrm{B}}$ \\
$\mathrm{K}\left(\mu \mathrm{g} \times \mathrm{g}^{-1}\right)$ & - & - & $6973.76 \pm 8.41^{\mathrm{A}}$ & $7010.19 \pm 126.81^{\mathrm{A}}$ \\
$\mathrm{Mg}\left(\mu \mathrm{g} \times \mathrm{g}^{-1}\right)$ & - & - & $1304.50 \pm 19.22^{\mathrm{A}}$ & $1205.81 \pm 25.90^{\mathrm{B}}$ \\
$\mathrm{Mn}\left(\mu \mathrm{g} \times \mathrm{g}^{-1}\right)$ & - & - & $10.14 \pm 10.14^{\mathrm{A}}$ & $9.76 \pm 9.77^{\mathrm{B}}$ \\
$\mathrm{Zn}\left(\mu \mathrm{g} \times \mathrm{g}^{-1}\right)$ & - & - & $6.72 \pm 0.06^{\mathrm{A}}$ & $6.15 \pm 0.04^{\mathrm{A}}$ \\
\hline
\end{tabular}

TAC: total anthocyanin content; TPC: total phenolic compounds; GAE: galic acid equivalent; Means \pm standard deviation ( $\mathrm{n}=3$ ); different superscript letters (lowercase for guabijú in natura; uppercase for guabijú lyophilized) in the lines indicate a significant difference by the ttest $(\mathrm{p}<0.05)$. Source: Authors.

The highest content of total anthocyanin content was observed for GINJ $\left(68.78 \mathrm{mg} \times 100 \mathrm{~g}^{-1}\right)$ and GLPD (220.12 mg $\left.\times 100 \mathrm{~g}^{-1}\right)$. The fact that GLPD has a higher content of total anthocyanin than GLPJ may be associated with the storage and drying process, since certain conditions may degrade the bioactive compounds, including $\mathrm{pH}$, temperature, oxygen concentration, and incidence of light (Schwartz et al., 2017). Seraglio et al. (2018) reported a higher anthocyanin content in the guabijú in natura in the advance stage of ripeness $\left(245.31 \mathrm{mg} \times 100 \mathrm{~g}^{-1}\right)$ and a lower content in an intermediate stage of maturation (64.67 mg $\left.\times 100 \mathrm{~g} \mathrm{~g}^{-1}\right)$. Dalla Nora, Müller, et al. (2014) evaluated the anthocyanin content on the fruit of guabijú and araçá red and reported a greater content for guabijú samples. The cited authors also evaluated the fresh, frozen, lyophilized and dried samples by hot air guabijú, and the anthocyanins identified were treatment-dependent. A higher content of total phenolic content was obtained in guabijú lyophilized, with the greatest predominance for the January harvest (1919.23 mg GAE $\left.\times 100 \mathrm{~g}^{-1}\right)$. Similarly, in the guabijú in natura, the total phenolic content was higher in samples from January (698.04 mg GAE $\times 100 \mathrm{~g}^{-1}$ ). Andrade et al. (2011) found levels of phenolic compounds between $2438.3-4613.4 \mathrm{mg} \mathrm{GAE} \times 100 \mathrm{~g}^{-1}$ for freeze-dried guabiju from different plantations. These data are higher compared to the present study (1822.62 and 1919.23 for 
guabijú liophylized December and January). The phenolic content is variable depending on the species, climatic conditions and other environmental factors (Andrade et al., 2011).

The antioxidant analysis - represented by the $\mathrm{EC}_{50}$ value - was higher for the GINJ fruit and, consequently, for the lyophilized powder from the same harvest, GLPJ (remember that lower $\mathrm{EC}_{50}$ values indicate greater antioxidant activity). Dalla Nora, Müller, et al. (2014) evaluated the antioxidant activity of fresh and lyophilized guabijú and described the same behavior: lyophilization increased the antioxidant activity of the fruit, as evidenced by the $\mathrm{EC}_{50}$ decrease $\left(6921.4\right.$ to $496.2 \mathrm{~g} \times 100 \mathrm{~g}^{-1}$ DPPH). The results observed in the present study (Table 2) for the antioxidant activity of both harvest times indicated lower $\mathrm{EC}_{50}$ values than those mentioned by the cited authors. According to Dalla Nora, Müller, et al. (2014), the polyphenols present in foods in natura may undergo transformations during the drying process, contributing to an increase in antioxidant activity. Furthermore, the water removal by the lyophilization process concentrates the dry mass, increasing the antioxidant activity. Based on the total anthocyanin content, total phenolic content, and antioxidant activity, both guabijú in natura and lyophilized may be considered sources of bioactive compounds.

The guabijú lyophilized mineral profile was mostly represented by $\mathrm{K}, \mathrm{Mg}$, and $\mathrm{Ca}$. There was a significant difference in $\mathrm{Ca}, \mathrm{Fe}, \mathrm{Mg}$, and $\mathrm{Mn}$ content between GLPD and GLPJ, with the highest content in samples harvested in December ( $\mathrm{p}<$ 0.05 ). For $\mathrm{Cu}, \mathrm{K}$ and $\mathrm{Zn}$, there were no significant differences ( $\mathrm{p}>0.05$ ). The most prevalent mineral in the samples was $\mathrm{K}$, as previously described by Seraglio et al. (2018) for guabijú, jabuticaba, and jambolão fruits. These authors also mentioned that in guabiju fruit at the higher ripeness stage, the sum of minerals was higher. According to the TTA, TSS, and RS, the guabijú from January was suggested to be in an advanced ripeness stage; however, according to the mineral profile, the samples from December and January are in similar stages of ripeness. Moreover, the mineral content on fruits may be associated with the soil and use of fertilizers, justifying the variations found between the fruits harvested in December and January (Cruz et al., 2015).

Several authors have already evidenced the presence of bioactive compounds for guabijú and other berry fruits. Table 3 shows a comparison of the data obtained with other studies considering the data available for berries in general. In the current study, the values obtained for total anthocyanin compounds in guabijú lyophilized were in the range described in the literature by two other studies. Moreover, the guabijú lyophilized present a high total anthocyanin content higher than that reported for red pitanga and acerola and a lower content than grumixama, jabuticaba, jambolão, açaí and camu-camu.

Regarding total phenolic compounds, the guabijú lyophilized analyzed presented slightly lower content compared with only one study available in the literature. On the other hand, guabijú had a higher total phenolic compound content than red pitanga and was comparable with acerola; if compared with grumixama, jabuticaba, and jambolão, the total phenolic compounds of guabijú were lower. The anthocyanins and phenolic compounds observed for guabijú in comparison with different berries reported in Table 3 reinforce the bioactive potential expression for the species studied. Moreover, it is noteworthy that the fruit in lyophilized form is richer in bioactive compounds. 
Table 3: Bioactive compounds of Brazilian berries.

\begin{tabular}{|c|c|c|c|c|}
\hline Compounds & Fruit & Specie & $\begin{array}{c}\text { Bioactive in fruit/extract } \\
\text { (d.b.) }\end{array}$ & References \\
\hline \multirow{17}{*}{$\begin{array}{c}\text { Total } \\
\text { anthocyanins } \\
\text { compounds } \\
\left(\mathrm{mg} 100 \mathrm{~g}^{-1}\right)\end{array}$} & Guabijú & Myrcianthes pungens & $201-220$ & Current research \\
\hline & Guabijú & Myrcianthes pungens & $64.57-245.31^{\mathrm{a}}$ & (Seraglio et al., 2018) \\
\hline & Guabijú & Myrcianthes punges & $334-531^{b}$ & (Andrade et al., 2011) \\
\hline & Red pitanga & Eugenia uniflora & $1.7^{b}$ & (Borges et al., 2015) \\
\hline & Acerola & Malpighia umbellata Rose & $182-215^{\mathrm{a}}$ & $\begin{array}{c}\text { (Vasavilbazo-Saucedo } \\
\text { et al., 2018) }\end{array}$ \\
\hline & Acerola & Malpighia glabra L. & $138^{\mathrm{b}}$ & (Borges et al., 2015) \\
\hline & Acerola & Malpighia emarginata & 210 & (Rufino et al., 2010) \\
\hline & Grumixama & Eugenia brasiliensis & 834 & (Reynertson et al., 2008) \\
\hline & Jabuticaba & Myrciaria cauliflora & $648-930^{a}$ & (Seraglio et al., 2018) \\
\hline & Jabuticaba & Myrciaria cauliflora & 412 & (Rufino et al., 2010) \\
\hline & Jabuticaba & Myrciaria cauliflora & $583-837$ & (Lima et al., 2011) \\
\hline & Jabuticaba & Myrciaria cauliflora & 684 & (Reynertson et al., 2008) \\
\hline & Jambolão & Syzygium cumini & 633 & (Reynertson et al., 2008) \\
\hline & Jambolão & Syzygium cumini & 618 & (Rufino et al., 2010) \\
\hline & Jambolão & Syzygium cumini & $377^{\mathrm{b}}$ & (Borges et al., 2015) \\
\hline & Açaí & Euterpe oleracea & 698 & (Rufino et al., 2010) \\
\hline & Сати-сати & Myrciaria dubia & 414 & (Rufino et al., 2010) \\
\hline \multirow{10}{*}{$\begin{array}{l}\text { Total phenolic } \\
\text { compounds } \\
(\mathrm{mg} \mathrm{GAE} \times 100 \\
\left.\mathrm{g}^{-1}\right)\end{array}$} & Guabijú & Myrcianthes pungens & $1823-1919$ & Current research \\
\hline & Guabijú & Myrcianthes pungens & $2438-4613$ & (Andrade et al., 2011) \\
\hline & Red pitanga & Eugenia uniflora & 1380 & (Borges et al., 2015) \\
\hline & Acerola & Malpighia umbellata Rose & $1034-2921$ & $\begin{array}{c}\text { (Vasavilbazo-Saucedo } \\
\text { et al., 2018) }\end{array}$ \\
\hline & Acerola & Malpighia glabra L. & 2870 & (Borges et al., 2015) \\
\hline & Grumixama & Eugenia brasiliensis & 2480 & (Reynertson et al., 2008) \\
\hline & Jabuticaba & Myrciaria cauliflora & 3160 & (Reynertson et al., 2008) \\
\hline & Jabuticaba & Myrciaria cauliflora & 4410 & (Reynertson et al., 2008) \\
\hline & Jambolão & Syzygium cumini & 2580 & (Borges et al., 2015) \\
\hline & Jambolão & Eugenia brasiliensis & 9950 & (Reynertson et al., 2008) \\
\hline
\end{tabular}

${ }^{a}$ Total monomeric anthocyanins; ${ }^{b}$ milligrams of cyanidin-3-glucoside equivalent $\times 100$ g; GAE: gallic acid equivalent; d.b.: dry base. Source: Authors.

Table 4 details the results obtained for the color parameters guabijú in natura and lyophilized. The color parameters analyzed for GIND and GINJ shells did not differ ( $\mathrm{p}>0.05$ ). For GIND and GINJ pulp, all parameters were significantly different $(\mathrm{p}<0.05)$. For GLPD and GLPJ, there was a significant difference with guabijú in natura peel and pulp for all color parameters. These variations reinforce the transformations in fruit due to the drying process. 
Table 4: Results of color analysis of guabijú in natura from December (GIND) and January (GIND) and lyophilized from December (GLPD) and January (GLPJ).

\begin{tabular}{|c|c|c|c|c|c|c|}
\hline & GIND & GINJ & GIND & GINJ & GLPD & GLPJ \\
\hline & \multicolumn{2}{|c|}{ External color (shell) } & \multicolumn{2}{|c|}{ Internal color (pulp) } & \multicolumn{2}{|c|}{ Milled powder color } \\
\hline $\mathrm{L}^{*}$ & $21.11 \pm 0.61^{\mathrm{e}}$ & $21.65 \pm 0.68^{\mathrm{e}}$ & $39.67 \pm 0.83^{b}$ & $32.03 \pm 0.76^{\mathrm{d}}$ & $47.94 \pm 0.72^{\mathrm{a}}$ & $36.99 \pm 0.72^{\mathrm{c}}$ \\
\hline$a^{*}$ & $-0.82 \pm 0.15^{\mathrm{e}}$ & $-1.07 \pm 0.01^{\mathrm{e}}$ & $1.25 \pm 0.01^{\mathrm{d}}$ & $2.30 \pm 0.48^{\mathrm{c}}$ & $8.85 \pm 0.20^{\mathrm{b}}$ & $13.44 \pm 0.15^{\mathrm{a}}$ \\
\hline$b^{*}$ & $2.15 \pm 0.02^{\mathrm{e}}$ & $2.18 \pm 0.08^{\mathrm{e}}$ & $25.85 \pm 0.87^{\mathrm{a}}$ & $14.66 \pm 0.17^{\mathrm{c}}$ & $16.66 \pm 0.21^{\mathrm{b}}$ & $8.95 \pm 0.17^{\mathrm{d}}$ \\
\hline
\end{tabular}

Means \pm standard deviation $(n=3)$; different superscript letters in the lines indicate a significant difference by the Tukey test $(\mathrm{p}<0.05)$. Source: Authors.

Considering $\mathrm{L}^{*}$, it was observed that the lyophilization process improved the lightness of guabijú lyophilized powder. Regarding a*, a positive value indicated that the pulp of guabijú in natura and lyophilized had a predominance of red color, while the shells of guabijú in natura have a predominance of green color. Considering $\mathrm{b}^{*}$, as the guabijú lyophilized was produced with shell and pulp, an intermediate value was observed for GLPD and GPLJ. However, as b* was positive, all samples had a predominance of yellow color. Comparing the lyophilized guabijú, it was observed that GLPD presented a dark color, with a predominance of yellow color. In contrast, the GLPJ was lighter, and the predominant color was red. Figure 1 also reinforces this perception. The differences in shade can be explained by the presence of anthocyanins. Deeper shades result from the absorption of light at a longer wavelength in the visible spectrum, caused by groups without chromophoric properties that cause color change when linked to the molecule. The presence of sugar molecules, copigmentation and changes in $\mathrm{pH}$ also contribute to the change in the shade of anthocyanins (Schwartz et al., 2017).

By PCA analysis, a two-dimensional consensual solution explained $94.07 \%$ of the variance of guabijú samples (Figure 2). Factor 1 explained $80.27 \%$ of the variance and was associated with the type of guabijú samples (in nature and lyophilized), while factor 2 explained $13.80 \%$ of the variance and was associated with harvesting time (December and January). Factor 1 discriminated guabijú in natura from lyophilized due to the higher moisture, pH, EC50 and b* values; on the other hand, guabijú lyophilized was highlighted due to the higher content of protein, lipids, ash, carbohydrate, total anthocyanin content, TTA, reducing sugar, total phenolic content, L*, and a*. Considering Factor 2, the December and January harvesting were discriminated especially by color parameters, $\mathrm{L}^{*}$ and $\mathrm{b}^{*}$ values, which were higher in guabijú in natura and lyophilized from December. 
Figure 2: Factor $1 x$ Factor 2 scores and loading plots of guabijú in natura from December (GIND) and January (GIND) and lyophilized from December (GLPD) and January (GLPJ).
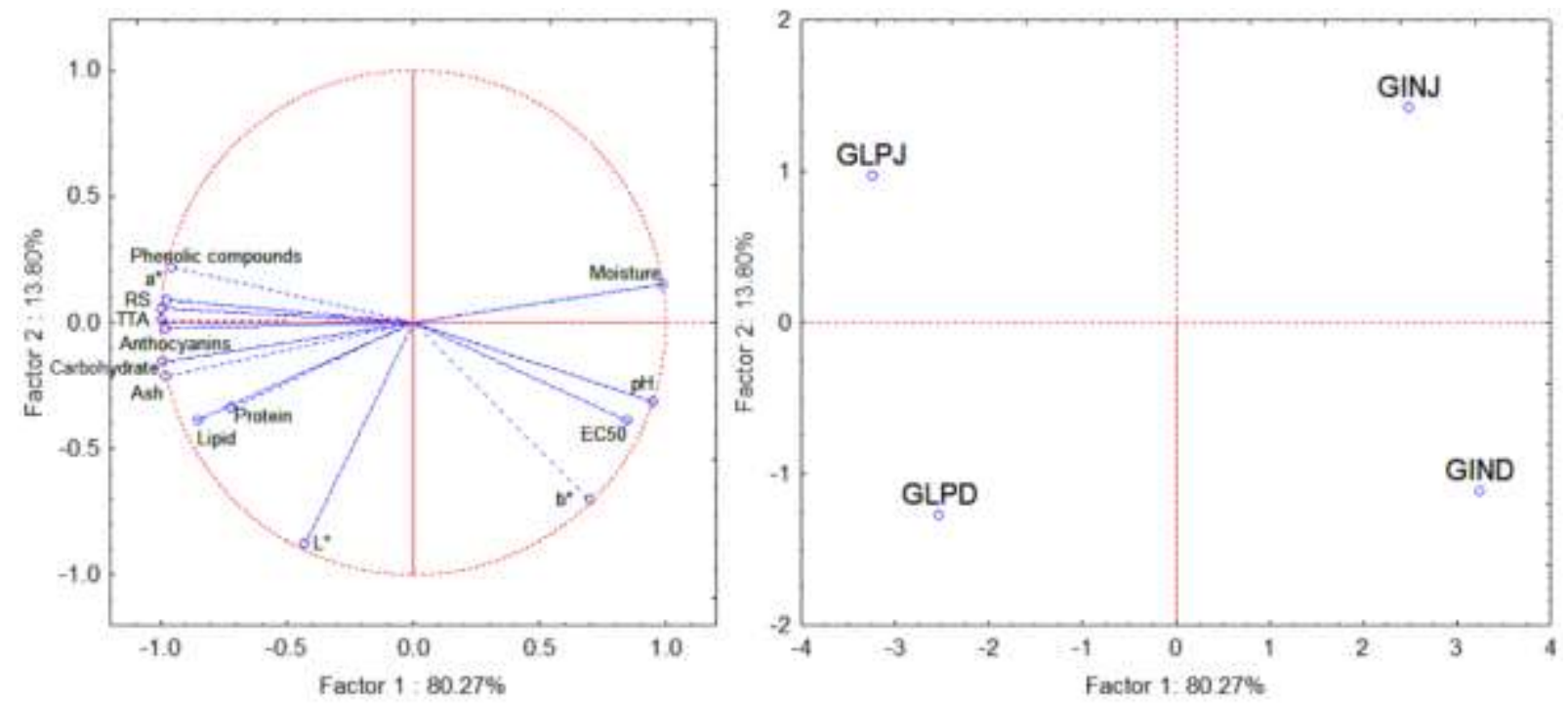

Source: Authors.

In general, the fruits of guabiju analyzed show the presence of anthocyanins, phenolic compounds, and antioxidant activity. Considering the fruits from two different harvest times, the January ones have greater acidity, solids, carbohydrates, reducing sugars, total anthocyanin content, total phenolic content, antioxidant activity, and more intense characteristic color. In the December harvest, the fruits presented the same compounds, however in lower content. This indicates that guabijú is a source of bioactive compounds and minerals; however, these are dependent on harvesting time, probably due climatic variations, soil, incidence of light, and precipitation.

The use of lyophilization as a preservation technique concentrated bioactive content in guabijú samples, improving total anthocyanin compounds, total phenolic compounds, sugars, and antioxidant activity. Between the freeze-dried powders of different harvesting times, December presented a higher content of total anthocyanin compounds and minerals, while January presented a higher antioxidant activity and total phenolic compounds. These differences may be related to processing conditions, incidence of light and environmental factors. Since this study, it is suggested for future studies the application of guabijú lyophilized in food, aiming to add health benefit properties for consumers and develop differentiated sensory attributes in foods.

\section{Conclusion}

Some differences between the guabijú harvested in December and January were evidenced by the proximal composition, bioactive profile, minerals, and color parameters. Moreover, the samples submitted to lyophilization showed good retention of bioactives, highlighting as a suitable method of processing to increase the stability without profound physicochemical changes.

\section{Acknowledgments}

This study was financed in part by the Coordenação de Aperfeiçoamento de Pessoal de Nível Superior - Brazil (CAPES) - Finance Code 001, Conselho Nacional de Desenvolvimento Científico e Tecnológico - Brazil (CNPq), and Fundação Araucária - Brazil. 


\section{References}

Andrade, J. M. M., Aboy, A. L., Apel, M. A., Raseira, M. C. B., Pereira, J. F. M., \& Henriques, A. T. (2011). Phenolic Composition in Different Genotypes of Guabiju Fruits (Myrcianthes pungens) and Their Potential as Antioxidant and Antichemotactic Agents. Journal of Food Science, 76(8), 1181-1187. https://doi.org/10.1111/j.1750-3841.2011.02375.x

Bagetti, M., Facco, E. M. P., Piccolo, J., Hirsch, G. E., Rodriguez-Amaya, D., Kobori, C. N., Vizzotto, M., \& Emanuelli, T. (2011). Physicochemical characterization and antioxidant capacity of pitanga fruits (Eugenia uniflora L.). Ciência e Tecnologia de Alimentos, 31(1), 147-154. https://doi.org/10.1590/s0101-20612011000100021

Betta, F. Della, Nehring, P., Seraglio, S. K. T., Schulz, M., Valese, A. C., Daguer, H., Gonzaga, L. V., Fett, R., \& Costa, A. C. O. (2018). Phenolic Compounds Determined by LC-MS/MS and In Vitro Antioxidant Capacity of Brazilian Fruits in Two Edible Ripening Stages. Plant Foods for Human Nutrition, 73(4), 302-307. https://doi.org/10.1007/s11130-018-0690-1

Borges, K. C., Azevedo, J. C., De Fátima Medeiros, M., \& Correia, R. T. P. (2015). Physicochemical characterization and bioactive value of tropical berry pomaces after spouted bed drying. Journal of Food Quality, 39(3), 192-200. https://doi.org/10.1111/jfq.12178

Brand-Williams, W., Cuvelier, M. E., \& Berset, C. (1995). Use of a free radical method to evaluate antioxidant activity. LWT - Food Science and Technology, 28(1), 25-30. https://doi.org/10.1016/S0023-6438(95)80008-5

Burckhardt, D., Queiroz, D. L., Junior, A. L. M., \& Wyniger, D. (2012). Tuthillia myrcianthis n . sp . (Hemiptera, Psylloidea): a new psyllid species on Guabiju (Myrcianthes pungens, Myrtaceae) from Brazil. Mitteilungen Der Schweizerischen Entomologischen Gesellschaft, 85, 209-220. https://ainfo.cnptia.embrapa.br/digital/bitstream/item/74589/1/2012bulletinsocieteentomologiquesuissev85p209.pdf.

Castro, N. M. T., Zamboni, V. P., Dovadoni, S., Cunha Neto, A., \& Rodrigues, J. L. (2015). Parâmetros de qualidade de polpas de frutas congeladas. Revista Do Instituto Adolfo Lutz, 74 (4), 426-436. http://www.ial.sp.gov.br/resources/insitutoadolfolutz/publicacoes/rial/10/rial74_4_completa/artigosseparados/1677.pdf

Chen, J., Zhao, Y., Tao, X. yun, Zhang, M., \& Sun, A. dong. (2015). Protective effect of blueberry anthocyanins in a CCL4-induced liver cell model. LWT Food Science and Technology, 60(2), 1105-1112. https://doi.org/10.1016/j.lwt.2014.10.010

Cruz, R., Morais, S., \& Casal, S. (2015). Mineral Composition Variability of Coffees: A Result of Processing and Production. In V. Preedy ( $1^{\circ}$ Ed.), Processing and Impact on Active Components in Food ( pp. 549-558). Elsevier Inc. https://doi.org/10.1016/B978-0-12-404699-3.00066-4

Dalla Nora, C., Jablonski, A., Rios, A. de O., Hertz, P. F., de Jong, E. V., \& Flôres, S. H. (2014). The characterisation and profile of the bioactive compounds in red guava (Psidium cattleyanum Sabine) and guabiju (Myrcianthes pungens (O. Berg) D. Legrand). International Journal of Food Science and Technology, 49(8), 1842-1849. https://doi.org/10.1111/ijfs.12493

Dalla Nora, C., Müller, C. D. R., de Bona, G. S., Rios, A. de O., Hertz, P. F., Jablonski, A., De Jong, E. V., \& Flôres, S. H. (2014). Effect of processing on the stability of bioactive compounds from red guava (Psidium cattleyanum Sabine) and guabiju (Myrcianthes pungens). Journal of Food Composition and Analysis, 34(1), 18-25. https://doi.org/10.1016/j.jfca.2014.01.006

Fior, C. S., Rodrigues, L. R., Calil, A. C., Leonhardt, C., de Souza, L. dos S., \& da Silva, V. S. (2010). Qualidade fisiológica de sementes de guabijuzeiro (Myrcianthes pungens (Berg) Legrand - Myrtaceae) em armazenamento. Revista Arvore, 34(3), 435-442. https://doi.org/10.1590/S0100-67622010000300007

Francis, F. J. (1982). Analysis of Anthocyanins. In P. Markakis. Anthocyanins As Food Colors (pp. 181-207). Elsevier Inc. https://doi.org/10.1016/B978-0-12472550-8.50011-1

IAL, (2008). Métodos físicos-quimicos para análise de Alimentos, (4a ed.) Instituto Adolfo Lutz, pp. 1020.

Kalschne, D. L., Detoni, E., Zimmer, F. C., Colla, E., \& Rodrigues, A. C. (2019). Brazilian Sources of Anthocyanins : Colored Pigments with Potential Health Benefits. Acta Scientific Nutritional Health ( ASNH ), 1(1), 30-35. https://doi.org/10.31080/ASNH.2019.S01.0008

Kalschne, D. L., Silva, N. K., Canan, C., Benassi, M. T., Flores, E. L., \& Leite, O. D. (2020). Main minerals and organic compounds in commercial roasted and ground coffee: an exploratory data analysis. Química Nova, XY(00), 1-6. https://doi.org/10.21577/0100-4042.20170653

Lamounier, M. L., Andrade, F. D. C., Mendonça, C. D. de, \& Magalhães, M. L. (2015). Desenvolvimento e caracterização de diferentes formulações de sorvetes enriquecidos com farinha da casca da jabuticaba (Myrciaria cauliflora). Revista Do Instituto de Laticínios Cândido Tostes, 70(2), 93-104. https://doi.org/10.14295/2238-6416.v70i2.400

Lima, A. de J. B., Corrêa, A. D., Saczk, A. A., Martins, M. P., \& Castilho, R. O. (2011). Anthocyanins, pigment stability and antioxidant activity in jabuticaba [Myrciaria cauliflora (Mart.) O. Berg]. Revista Brasileira de Fruticultura, 33(3), 877-887. https://doi.org/10.1590/s0100-29452011000300023

Maldonade, I. R., Carvalho, P. G., \& Ferreira, N. A. (2013). Protocolo para determinação de açúcares totais em hortaliças pelo método de DNS. Empresa Brasileira de Pesquisa Agropecuária - Embrapa Hortaliças, 85, 1-4. https://ainfo.cnptia.embrapa.br/digital/bitstream/item/81580/1/cot-85.pdf.

Reynertson, K. A., Yang, H., Jiang, B., Basile, M. J., \& Kennelly, E. J. (2008). Quantitative analysis of antiradical phenolic constituents from fourteen edible Myrtaceae fruits. Food Chemistry, 109(4), 883-890. https://doi.org/10.1016/j.foodchem.2008.01.021

Rufino, M. do S. M., Alves, R. E., Brito, E. S. de, Morais, S. M. de, Sampaio, C. de G., Perez-Jimenéz, J., \& Saura-Calixto, F. D. (2007). Metodologia Científica: Determinação da Atividade Antioxidante Total em Frutas pela Captura do Radical Livre DPPH. Empresa Brasileira de Pesquisa Agropecuária Embrapa Agroindústria Tropical, 1-4. https://ainfo.cnptia.embrapa.br/digital/bitstream/CNPAT/10224/1/Cot_127.pdf.

Rufino, M. do S. M., Alves, R. E., de Brito, E. S., Pérez-Jiménez, J., Saura-Calixto, F., \& Mancini-Filho, J. (2010). Bioactive compounds and antioxidant capacities of 18 non-traditional tropical fruits from Brazil. Food Chemistry, 121(4), 996-1002. https://doi.org/10.1016/j.foodchem.2010.01.037 
Research, Society and Development, v. 10, n. 3, e37810313337, 2021

(CC BY 4.0) | ISSN 2525-3409 | DOI: http://dx.doi.org/10.33448/rsd-v10i3.13337

Sarmento, M. B., Silva, A. C. S. da, \& Silva, C. S. da. (2012). Recursos genéticos de frutas nativas da família Myrtaceae no Sul do Brasil. Fórum, 24, 250262. http://snida.agricultura.gov.br/binagri/bases/agb/Agb_Docs_Fonte/BR2013007956.pdf

Schwartz, S. J., Cooperstone, J. L., Cichon, M. J., Elbe, J. H. von, \& Giusti, M. M. (2017). Colorants. In S. Damodaran \& K. L. Parkin (Eds.), Fennema's Food Chemistry (5॰, pp. 708-724). Taylor \& Francis.

Seraglio, S. K. T., Schulz, M., Nehring, P., Della Betta, F., Valese, A. C., Daguer, H., Gonzaga, L. V., Fett, R., \& Costa, A. C. O. (2018). Nutritional and bioactive potential of Myrtaceae fruits during ripening. Food Chemistry, 239, 649-656. https://doi.org/10.1016/j.foodchem.2017.06.118

Singleton, V. L., Orthofer, R., \& Lamuela-Raventós, R. M. (1999). Analysis of total phenols and other oxidation substrates and antioxidants by means of folinciocalteu reagent. In L. Packer (Ed.), Methods in Enzymology (Vol. 299, pp. 152-178). Academic Press, Inc. https://doi.org/10.1016/S0076-6879(99)99017-1

Souza, L. dos S. de. (2010). Caracterização de frutos e propagação vegetativa de guabijuzeiro (Myrcianthes pungens (o.berg) d. legrand). In Dissertação de Mestrado em Fitotecnia. Universidade Federal do Rio Grande do Sul.

Vasavilbazo-Saucedo, A., Almaraz-Abarca, N., González-Ocampo, H. A., Ávila-Reyes, J. A., González-Valdez, L. S., Luna-González, A., Delgado-Alvarado, E. A., \& Torres-Ricario, R. (2018). Phytochemical characterization and antioxidant properties of the wild edible acerola malpighia umbellata rose. CYTA Journal of Food, 16(1), 698-706. https://doi.org/10.1080/19476337.2018.1475424

Vieira, A. P., Nicoleti, J. F., \& Telis, V. R. N. (2012). Liofilização de fatias de abacaxi: avaliação da cinética de secagem e da qualidade do produto. Brazilian Journal of Food Technology, 15(1), 50-58. https://doi.org/10.1590/s1981-67232012000100006 